\title{
Benzyllithium from methylated benzylamine and its ammonium salt via naphthalene-catalyzed carbon-nitrogen bond reductive cleavage
}

\author{
David Guijarro, Pedro J. Martínez, Carmen Nájera, and Miguel Yus* \\ Departamento de Química Orgánica, Facultad de Ciencias, Universidad de Alicante, Apdo. 99, \\ E-03080 Alicante, Spain \\ E-mail:yus@ua.es
}

Dedicated to Professor Enrique Meléndez on his $70^{\text {th }}$ birthday

(received 10 Apr 03; accepted 29 May 03; published on the web 30 May 03)

\begin{abstract}
The reaction of $\mathrm{N}, \mathrm{N}$-dimethylbenzylamine with lithium powder and a catalytic amount of naphthalene, followed by addition of different electrophiles, gave the expected reaction products in low yield. However, yields could be improved by using the corresponding ammonium salt instead of the amine. When $N, N, N$-trimethylbenzylammonium iodide was submitted to the naphthalene-catalyzed lithiation process, followed by reaction with several electrophiles, the expected reaction products were obtained in moderate to good yields.
\end{abstract}

Keywords: Lithium, lithiation, carbon-nitrogen bond reductive cleavage, amine, ammonium salt

\section{Introduction}

The generation of allylic and benzylic organolithium reagents by direct lithiation of the corresponding halides is difficult to achieve, because a Wurtz-type reaction takes place, which reduces to a minimum the amounts of allyllithium and benzyllithium obtained. ${ }^{1,2}$ Other alternative methodologies have been reported, involving deprotonation reactions, ${ }^{3}$ transmetallation processes, ${ }^{4}$ or reductive cleavage of ethers, ${ }^{5}$ but they have a limited application.

In the last few years, we have been using an arene-catalyzed lithiation ${ }^{6,7}$ to prepare organolithium compounds under very mild reaction conditions. The use of an excess of lithium powder and a catalytic amount of an arene [mainly naphthalene or 4,4'-di-tert-butylbiphenyl (DTBB)] allowed us to generate simple organolithium compounds starting from non-halogenated materials, ${ }^{8}$ and functionalized organolithium compounds ${ }^{9}$ by chlorine-lithium exchange or by ring opening of heterocycles. ${ }^{10,11}$ We have been able to apply this lithiation process to the preparation of allylic and benzylic organolithium reagents via reductive decyanation of nitriles, ${ }^{12}$ addition of lithium to double bonds ${ }^{13}$ or reductive cleavage of several carbon-heteroatom bonds 
including carbon-oxygen, ${ }^{14}$ carbon-sulfur ${ }^{15}$ and carbon-nitrogen bonds. ${ }^{16}$ Concerning the latter, several amino functionalized benzylic organolithium compounds could be prepared using nitrogen containing heterocycles as starting materials, such as 2-phenylaziridines, ${ }^{16 a}$ 2phenylazetidines, ${ }^{16 \mathrm{~b}}$ 2-phenylpyrrolidines ${ }^{16 \mathrm{c}}$ and benzo- fused pyrrolidines and piperidines. ${ }^{16 \mathrm{c}}$ However, the generation of simple allylic or benzylic organolithium compounds via reductive cleavage of carbon-nitrogen bonds has not been described yet and, to the best of our knowledge, no reports have appeared in the literature concerning that matter. ${ }^{17}$ In this paper we report on the generation of benzyllithium by a naphthalene-catalyzed lithiation of benzylic amines and ammonium salts.

\section{Results and Discussion}

The reaction of commercially available $N, N$-dimethylbenzylamine $\mathbf{1}$ (Scheme 1 ) with an excess of lithium powder and a catalytic amount of naphthalene (1:0.2 molar ratio) in THF at room temperature, followed by addition of several electrophilic reagents at $-30^{\circ} \mathrm{C}$, gave the expected products 2a-2c in low yields (Table 1, entries 1-3). In all cases, toluene was detected (GC-MS) in the final reaction mixture, its formation being explained by a proton abstraction from the reaction medium $^{18}$ by the generated benzyllithium, due to the long time $(5-7 \mathrm{~h})$ needed for complete disappearance of the amine at room temperature.

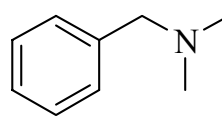

1

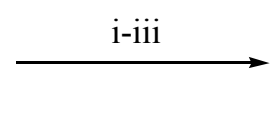

$$
\begin{aligned}
& \text { 2b: } \mathrm{E}=\mathrm{Bu}^{\mathrm{t}} \mathrm{CHOH} \\
& \text { 2c: } \mathrm{E}=\left(\mathrm{CH}_{2}\right)_{5} \mathrm{COH}
\end{aligned}
$$$$
\text { 2a: } \mathrm{E}=\mathrm{Me}_{3} \mathrm{Si}
$$

Scheme 1. Reagents and conditions: $\mathrm{i}, \mathrm{Li}, \mathrm{C}_{10} \mathrm{H}_{8}(10 \mathrm{~mol} \%)$, THF, $25^{\circ} \mathrm{C}$; ii, $\mathrm{E}^{+}=\mathrm{Me}_{3} \mathrm{SiCl}$, $\mathrm{Bu}{ }^{t} \mathrm{CHO},\left(\mathrm{CH}_{2}\right)_{5} \mathrm{CO},-30$ to $0^{\circ} \mathrm{C}$; iii, $\mathrm{HCl}-\mathrm{H}_{2} \mathrm{O}$.

In order to improve yields, we thought that it would be necessary to transform the amino group in a better leaving group. Thus, we decided to prepare the ammonium salt $\mathbf{3}$ (Scheme 2) by methylation of amine $\mathbf{1}$ and test it in the lithiation process. The naphthalene-catalyzed lithiation of compound 3 in THF at room temperature, followed by reaction with several electrophiles at $30^{\circ} \mathrm{C}$, afforded the expected products $2 \mathbf{a}-2 \mathbf{f}$ in moderate to good yields (Table 1, entries 4-9). Since ammonium salt 3 was not soluble in THF, the end of the lithiation process was determined visually, i.e., the mixture of lithium, naphthalene and compound 3 in THF was stirred at room temperature until no white solid (ammonium salt 3) remained in suspension. At that moment, the reaction flask was cooled down to $-30^{\circ} \mathrm{C}$ and the corresponding electrophile was added. As 
expected, yields were improved considerably in comparison with the ones obtained using amine 1 as source of benzyllithium (compare entries 1-3 with entries 4-6, respectively). The formation of toluene was also detected (GC-MS) in the crude mixture of all the reactions. Again, the long reaction times $(1-2 \mathrm{~h})$ needed to complete the carbon-nitrogen reductive cleavage at room temperature could cause the decomposition of some benzyllithium by proton abstraction from the reaction medium, ${ }^{18}$ which could be responsible for the moderate yields obtained in most cases.

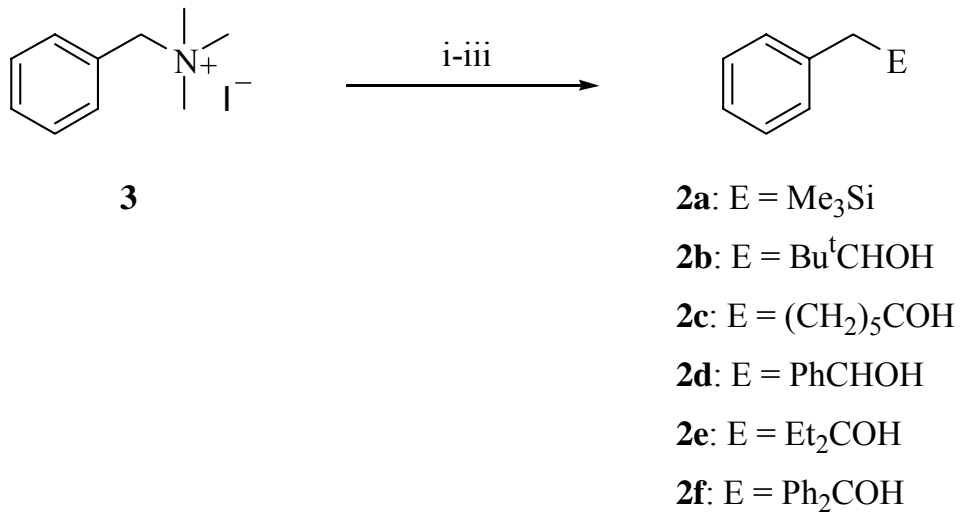

Scheme 2. Reagents and conditions: $\mathrm{i}, \mathrm{Li}, \mathrm{C}_{10} \mathrm{H}_{8}(10 \mathrm{~mol} \%)$, THF, $25^{\circ} \mathrm{C}$; ii, $\mathrm{E}^{+}=\mathrm{Me}_{3} \mathrm{SiCl}$, $\mathrm{Bu}^{\mathrm{t}} \mathrm{CHO},\left(\mathrm{CH}_{2}\right)_{5} \mathrm{CO}, \mathrm{PhCHO}, \mathrm{Et}_{2} \mathrm{CO}, \mathrm{Ph}_{2} \mathrm{CO},-30$ to $0^{\circ} \mathrm{C}$; iii, $\mathrm{HCl}-\mathrm{H}_{2} \mathrm{O}$.

Table 1. Lithiation of amine $\mathbf{1}$ and ammonium salt $\mathbf{3}$ and reaction with several electrophiles

\begin{tabular}{cccccc}
\hline & & & \multicolumn{3}{c}{ Product $^{\mathrm{a}}$} \\
\cline { 3 - 6 } Entry & Substrate & $\mathrm{E}^{+}$ & $\mathrm{No}$ & $\mathrm{E}$ & ${\text { Yield }(\%)^{\mathrm{b}}}^{\mathrm{b}}$ \\
\hline 1 & $\mathbf{1}$ & $\mathrm{Me}_{3} \mathrm{SiCl}$ & $\mathbf{2 a}$ & $\mathrm{Me}_{3} \mathrm{Si}$ & 12 \\
2 & $\mathbf{1}$ & $\mathrm{Bu}^{\mathrm{t}} \mathrm{CHO}$ & $\mathbf{2 b}$ & $\mathrm{Bu}^{\mathrm{t}} \mathrm{CHOH}$ & 16 \\
3 & $\mathbf{1}$ & $\left(\mathrm{CH}_{2}\right)_{5} \mathrm{CO}$ & $\mathbf{2 c}$ & $\left(\mathrm{CH}_{2}\right)_{5} \mathrm{COH}$ & 13 \\
4 & $\mathbf{3}$ & $\mathrm{Me}_{3} \mathrm{SiCl}$ & $\mathbf{2 a}$ & $\mathrm{Me}_{3} \mathrm{Si}$ & 36 \\
5 & $\mathbf{3}$ & $\mathrm{Bu}^{\mathrm{t} C H O}$ & $\mathbf{2 b}$ & $\mathrm{Bu}^{\mathrm{t}} \mathrm{CHOH}$ & 41 \\
6 & $\mathbf{3}$ & $\left(\mathrm{CH}_{2}\right)_{5} \mathrm{CO}$ & $\mathbf{2 c}$ & $\left(\mathrm{CH}_{2}\right)_{5} \mathrm{COH}$ & 34 \\
7 & $\mathbf{3}$ & $\mathrm{PhCHO}$ & $\mathbf{2 d}$ & $\mathrm{PhCHOH}$ & 22 \\
9 & $\mathbf{3}$ & $\mathrm{Et}_{2} \mathrm{CO}$ & $\mathbf{2 e}$ & $\mathrm{Et}_{2} \mathrm{COH}$ & 36 \\
\hline & $\mathbf{3}$ & $\mathrm{Ph}_{2} \mathrm{CO}$ & $\mathbf{2 f}$ & $\mathrm{Ph}_{2} \mathrm{COH}$ & 76 \\
\hline
\end{tabular}

${ }^{a}$ All compounds 2 were $\geq 95 \%$ pure (GLC and/or $300 \mathrm{MHz}{ }^{1} \mathrm{H}$ NMR). ${ }^{\text {b }}$ Isolated yield after column chromatography (silica gel, hexane/ethyl acetate) based on the starting material 1 or $\mathbf{3}$. 
Next, we investigated the scope of this methodology. Benzylic ammonium salts 4-8 (Figure 1) were prepared and tested under the reaction conditions described above for the lithiation of compound 3 using 3-pentanone and pivalaldehyde as electrophilic reagents. However, the expected addition products were not formed in any case, compounds derived from trimethylamino-hydrogen exchange being the only reaction products detected (GC-MS). Therefore, it seems that, under the reaction conditions tried, the generated organolithium reagents prefer to abstract a proton from the reaction medium ${ }^{18}$ rather than add to the carbonyl group. A possible intra- or intermolecular ortho-lithiation can not be ruled out.

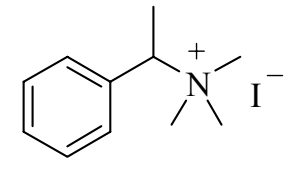

4

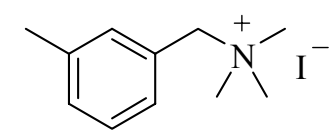

5

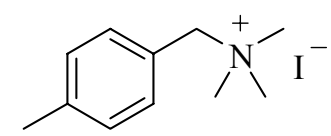

6<smiles>COc1ccc(C[N+](C)(C)I)cc1</smiles>

7<smiles>C[N+](C)(C)Cc1cccc2ccccc12</smiles>

8

\section{Figure 1}

\section{Conclusions}

In this paper, we have presented a new method for the generation of benzyllithium via reductive cleavage of carbon-nitrogen bonds. Although the methodology is limited, it is useful because the preparation of benzyllithium in good yields is not an easy task. Moreover, it represents a direct way to transform ammonium salts, and consequently their precursor amines, into non functionalized benzyllithium reagents, which, to the best of our knowledge, has not been described yet.

\section{Experimental Section}

General Procedures. For general information, see reference 13c. Starting amines, all other reagents used for the synthesis of ammonium salts 3-8, naphthalene and the electrophiles were commercially available (Acros, Aldrich) and were used without further purification. Lithium powder was prepared according to the procedure described in reference $13 \mathrm{c}$. Commercially available $n$-butyllithium was titrated with a $1 \mathrm{M}$ solution of sec-butanol in xylene using 1,10- 
phenanthroline as indicator. ${ }^{19}$ Commercially available anhydrous THF $(99.9 \%$, water content $\leq$ $0.006 \%$, Acros) was used as solvent in all the lithiation reactions. NMR spectra were recorded on a Bruker $\mathrm{AC}-300\left(300 \mathrm{MHz}\right.$ for ${ }^{1} \mathrm{H}$ and $75 \mathrm{MHz}$ for ${ }^{13} \mathrm{C}$ ) using $\mathrm{CD}_{3} \mathrm{OD}$ as solvent and internal standard (3.30 ppm for ${ }^{1} \mathrm{H}$ and $49.0 \mathrm{ppm}$ for ${ }^{13} \mathrm{C}$ ) for ammonium salts 3-8, and $\mathrm{CDCl}_{3}$ as solvent and TMS $\left(0.00 \mathrm{ppm},{ }^{1} \mathrm{H}\right)$ and $\mathrm{CDCl}_{3}\left(77.0 \mathrm{ppm},{ }^{13} \mathrm{C}\right)$ as internal standards for the rest of compounds. Chemical shifts are given in $\delta(\mathrm{ppm})$ and coupling constants $(J)$ in $\mathrm{Hz} .{ }^{13} \mathrm{C}$ NMR assignments were made on the basis of DEPT experiments.

\section{General procedure for naphthalene-catalyzed lithiation of amine 1}

A solution of commercially available amine $1(0.17 \mathrm{~mL}, 1.0 \mathrm{mmol})$ in THF $(2 \mathrm{~mL})$ was dropwise added to a green suspension of lithium powder $(70 \mathrm{mg}, 10.0 \mathrm{mmol})$ and naphthalene $(26 \mathrm{mg}, 0.2$ $\mathrm{mmol})$ in THF $(5 \mathrm{~mL})$, under Ar, at room temperature. The reaction mixture was stirred until complete disappearance of the amine was verified by GC-MS (5-7 h). The reaction flask was then cooled to $-30^{\circ} \mathrm{C}$, the corresponding electrophile $(1.2 \mathrm{mmol})$ was added and stirring was continued for $1 \mathrm{~h}$ allowing the temperature to rise to $0^{\circ} \mathrm{C}$. The reaction was then hydrolyzed with water $(5 \mathrm{~mL})$ at the same temperature and acidified with $2 \mathrm{M} \mathrm{HCl}(5 \mathrm{~mL})$. The mixture was extracted with ethyl acetate $(3 \times 15 \mathrm{~mL})$ and the combined organic phases were washed with saturated aqueous $\mathrm{NaHCO}_{3}(5 \mathrm{~mL})$, water $(5 \mathrm{~mL})$ and brine $(5 \mathrm{~mL})$, being then dried over sodium sulfate. After evaporation of the solvents (15 Torr), the resulting residue was purified by column chromatography (silica gel, hexane/ethyl acetate), affording the expected products in the yields indicated in Table 1. Compounds $2 \mathbf{a}^{14 \mathrm{~b}}{ }^{2} \mathbf{2} \mathbf{b}^{14 \mathrm{e}}$ and $\mathbf{2} \mathbf{c},{ }^{14 \mathrm{a}}$ previously prepared in our laboratory, were characterized by comparison of their physical and spectroscopic data with authentic samples.

Preparation of ammonium salt 3. Methyl iodide $(3.2 \mathrm{~mL}, 50 \mathrm{mmol})$ was added to a solution of commercially available amine $1(1.7 \mathrm{~mL}, 10.0 \mathrm{mmol})$ in THF $(30 \mathrm{~mL})$ at room temperature and the resulting mixture was stirred for $3 \mathrm{~h}$. The obtained solid was allowed to settle overnight and then it was filtered, washed with anhydrous THF and dried under reduced pressure (15 Torr), affording pure ammonium salt 3 in 95\% yield.

Benzyltrimethylammonium iodide (3). ${ }^{20}$ white solid; $\delta_{\mathrm{H}} 3.16(9 \mathrm{H}, \mathrm{s}, 3 \mathrm{x} \mathrm{Me}), 4.63(2 \mathrm{H}, \mathrm{s}$, $\left.\mathrm{CH}_{2}\right), 7.48-7.67(5 \mathrm{H}, \mathrm{m}, \mathrm{ArH}) ; \delta_{\mathrm{C}} 53.3$ (3C, 3 x Me), $70.05\left(\mathrm{CH}_{2}\right), 129.05,130.25(2 \mathrm{C}), 131.85$, $134.1(2 \mathrm{C})(\mathrm{ArC})$.

\section{General procedure for synthesis of ammonium salts 4-8}

$n$-Butyllithium (10.0 mmol, $6.25 \mathrm{~mL}$ of a $1.6 \mathrm{M}$ solution in hexane) was dropwise added to a solution of the corresponding benzylic primary amine $(10.0 \mathrm{mmol})$ in anhydrous THF $(10 \mathrm{~mL})$, under $\mathrm{Ar}$, at $0^{\circ} \mathrm{C}$. After stirring for $10 \mathrm{~min}$. at the same temperature, methyl iodide $(0.63 \mathrm{~mL}$, $10.0 \mathrm{mmol}$ ) was added. After 10 more min., the addition of the same amounts of $n$-butyllithium and methyl iodide was repeated as above keeping the reaction temperature at $0^{\circ} \mathrm{C}$. The reaction was then hydrolized with water $(20 \mathrm{~mL})$, extracted with ethyl acetate $(3 \times 15 \mathrm{~mL})$ and the 
combined organic phases were dried over sodium sulfate. After evaporation of the solvents, ${ }^{1} \mathrm{H}$ NMR spectrum of the crude mixtures revealed the formation of the expected $N, N$-dimethyl benzylic amines, which were used in the next step without further purification. The crude reaction mixtures were dissolved in anhydrous THF $(30 \mathrm{~mL})$ and treated with an excess of methyl iodide as described above for the preparation of ammonium salt 3 . The obtained solids were allowed to settle overnight and then they were filtered, washed with anhydrous THF and dried under reduced pressure (15 Torr), affording pure ammonium salts 4-8 in the following yields: 4 (94\%), 5 (59\%), 6 (50\%), 7 (66\%) and 8 (86\%). Some spectroscopic data follow:

Trimethyl(1-phenylethyl)ammonium iodide (4). ${ }^{21}$ white solid; $\delta_{\mathrm{H}} 1.89(3 \mathrm{H}, \mathrm{d}, J=7.0 \mathrm{~Hz}$, $\mathrm{MeC}), 3.21\left(9 \mathrm{H}, \mathrm{s}, \mathrm{Me}_{3} \mathrm{~N}\right), 5.05(1 \mathrm{H}, \mathrm{q}, J=7.0 \mathrm{~Hz}, \mathrm{CHMe}), 7.46-7.81(5 \mathrm{H}, \mathrm{m}, \mathrm{ArH}) ; \delta_{\mathrm{C}} 15.65$ $(\mathrm{MeC}), 52.05\left(3 \mathrm{C}, \mathrm{Me}_{3} \mathrm{~N}\right), 75.05(\mathrm{CHMe}), 130.2(3 \mathrm{C}), 131.65(2 \mathrm{C}), 134.25$ (ArC).

Trimethyl(3-methylbenzyl)ammonium iodide (5). ${ }^{22}$ white solid; $\delta_{\mathrm{H}} 2.38(3 \mathrm{H}, \mathrm{s}, \mathrm{MeC}), 3.13$ $\left(9 \mathrm{H}, \mathrm{s}, \mathrm{Me}_{3} \mathrm{~N}\right), 4.56\left(2 \mathrm{H}, \mathrm{s}, \mathrm{CH}_{2}\right), 7.24-7.50(4 \mathrm{H}, \mathrm{m}, \mathrm{ArH}) ; \delta_{\mathrm{C}} 21.35(\mathrm{MeC}), 53.3\left(3 \mathrm{C}, \mathrm{Me}_{3} \mathrm{~N}\right)$, $70.35\left(\mathrm{CH}_{2}\right), 128.95,130.15,131.1,132.6,134.6,140.45$ (ArC).

Trimethyl(4-methylbenzyl)ammonium iodide (6). ${ }^{23}$ white solid; $\delta_{\mathrm{H}} 2.35(3 \mathrm{H}, \mathrm{s}, \mathrm{MeC}), 3.07$ $\left(9 \mathrm{H}, \mathrm{s}, \mathrm{Me}_{3} \mathrm{~N}\right), 4.50\left(2 \mathrm{H}, \mathrm{s}, \mathrm{CH}_{2}\right), 7.29,7.43$ (2H each, 2d, J = 7.9 Hz each, ArH); $\delta_{\mathrm{C}} 21.35$ $(\mathrm{MeC}), 53.15\left(3 \mathrm{C}, \mathrm{Me}_{3} \mathrm{~N}\right), 70.1\left(\mathrm{CH}_{2}\right), 126.05,130.85(2 \mathrm{C}), 133.95$ (2C), 142.4 (ArC).

(4-Methoxybenzyl)trimethylammonium iodide (7). ${ }^{24}$ white solid; $\delta_{\mathrm{H}} 3.06(9 \mathrm{H}, \mathrm{s}, \mathrm{Me} 3 \mathrm{~N}), 3.78$ $(3 \mathrm{H}, \mathrm{s}, \mathrm{MeO}), 4.49\left(2 \mathrm{H}, \mathrm{s}, \mathrm{CH}_{2}\right), 6.99,7.47$ (2H each, 2d, $J=8.6 \mathrm{~Hz}$ each, $\left.\mathrm{ArH}\right) ; \delta_{\mathrm{C}} 55.8,(3 \mathrm{C}$, $\left.\mathrm{Me}_{3} \mathrm{~N}\right), 58.9(\mathrm{MeO}), 72.9\left(\mathrm{CH}_{2}\right), 118.45(2 \mathrm{C}), 123.75,138.4(2 \mathrm{C}), 165.9(\mathrm{ArC})$.

Trimethyl(1-naphthylmethyl)ammonium iodide (8). ${ }^{25}$ white solid; $\delta_{\mathrm{H}} 3.20\left(9 \mathrm{H}, \mathrm{s}, \mathrm{Me}_{3} \mathrm{~N}\right)$, $5.13\left(2 \mathrm{H}, \mathrm{s}, \mathrm{CH}_{2}\right), 7.50-8.48(7 \mathrm{H}, \mathrm{m}, \mathrm{ArH}) ; \delta_{\mathrm{C}} 53.85\left(3 \mathrm{C}, \mathrm{Me}_{3} \mathrm{~N}\right), 66.4\left(\mathrm{CH}_{2}\right), 124.7,126.25$, $126.45,127.6,128.95,130.45,132.2,132.3,133.15,134.95$ (ArC).

\section{General procedure for naphthalene-catalyzed lithiation of ammonium salts 3-8}

A mixture of lithium powder $(70 \mathrm{mg}, 10.0 \mathrm{mmol})$, naphthalene $(26 \mathrm{mg}, 0.2 \mathrm{mmol})$ and the corresponding ammonium salt 3-8 $(1.0 \mathrm{mmol})$ in THF $(5 \mathrm{~mL})$, under Ar, was stirred at room temperature until the white solid (ammonium salt) that was in suspension had disappeared completely $(1-2 \mathrm{~h})$. The reaction flask was then cooled to $-30^{\circ} \mathrm{C}$, the corresponding electrophile (1.2 mmol) was added and stirring was continued for $1 \mathrm{~h}$ allowing the temperature to rise to $0^{\circ} \mathrm{C}$. The reaction was then hydrolyzed with water $(5 \mathrm{~mL})$ at the same temperature and acidified with $2 \mathrm{M} \mathrm{HCl}(5 \mathrm{~mL})$. The mixture was extracted with ethyl acetate $(3 \times 15 \mathrm{~mL})$ and the combined organic phases were washed with saturated aqueous $\mathrm{NaHCO}_{3}(5 \mathrm{~mL})$, water $(5 \mathrm{~mL})$ and brine $(5$ $\mathrm{mL}$ ), being then dried over sodium sulfate. After evaporation of the solvents (15 Torr), the resulting residue was purified by column chromatography (silica gel, hexane/ethyl acetate), affording the expected products in the yields indicated in Table 1 . Compounds $2 \mathbf{2} \mathbf{a},{ }^{14 \mathbf{b}} \mathbf{2} \mathbf{b},{ }^{14 \mathrm{e}}$ and 2c-2f, ${ }^{14 a}$ previously prepared in our laboratory, were characterized by comparison of their physical and spectroscopic data with authentic samples. 


\section{Acknowledgements}

This work was financially supported by the DGES from the Spanish Ministerio de Educación y Cultura (MEC) (project no. PB97-0133 and BQU2001-0538). P. M. thanks the University of Alicante for financial support.

\section{References and notes}

1. (a) Wakefield, B. J. In Comprehensive Organic Chemistry; Barton, D.; Ollis, W. D. Eds.; Pergamon Press: Oxford, England, 1979; Vol. 3, Chapter 15.1. (b) Negishi, E. I. Organometallics in Organic Synthesis; Wiley: New York, 1980, p 96. (c) Wakefield, B. J. Organolithium methods; Academic Press: London, 1988; Chapter 3. (d) Ley, S. V.; Kouklovsky, C. In Comprehensive Organic Functional Group Transformations; Katritzky, A. R.; Meth-Cohn, O.; Rees, C. W. Eds.; Pergamon: Cambridge, England, 1995; Vol. 2, Chapter 2.11.

2. We have been able to trap the allylic and benzylic organolithium reagents generated by an arene catalyzed lithiation of allylic and benzylic chlorides (2a) and fluorides (2b) under Barbier type reaction conditions: (a) Gómez, C.; Huerta, F. F.; Yus, M. Tetrahedron 1998, 54, 1853. (b) Guijarro, D.; Yus, M. J. Organomet. Chem. 2001, 624, 53.

3. (a) Lochmann, L.; Pospisil, J.; Lim, D. Tetrahedron Lett. 1966, 257. (b) Schlosser, M. J. Organomet. Chem. 1967, 8, 9. (c) Akiyama, S.; Hooz, J. Tetrahedron Lett. 1973, 4115.

4. (a) Schlosser, M. In Organometallics in Synthesis; Schlosser M., Ed.; J. Wiley \& Sons: Chichester, 1994, p 53. (b) Schlenk, W.; Holtz, J. Ber. Dtsch. Chem. Ges. 1917, 50, 262. (c) Eisch, J. J. Organometallic Synthesis; Academic Press: New York, 1981; Vol. 2, p 92.

5. (a) Eisch, J. J.; Jacobs, A. M. J. Org. Chem. 1963, 28, 2145. (b) Eisch, J. J. Organometallic Synthesis; Academic Press: New York, 1981; Vol. 2, p 91.

6. For reviews, see: (a) Yus, M. Chem. Soc. Rev. 1996, 25, 155. (b) Ramón, D. J.; Yus, M. Eur. J. Org. Chem. 2000, 225. (c) Yus, M. Synlett 2001, 1197. (d) Yus, M.; Ramón, D. J. Latv. J. Chem. 2002, 79. (e) Ramón, D. J.; Yus, M. Rev. Cubana Quim. 2002, 14, 76. (f) Yus, M. In The Chemistry of Organolithium Compounds; Rappoport, Z.; Mareck, I. Eds.; J. Wiley \& Sons: Chichester, 2003; in press. For a mechanistic study, see: (g) Yus, M.; Herrera, R. P.; Guijarro, A. Tetrahedron Lett. 2001, 42, 3455. (h) Yus, M.; Herrera, R. P.; Guijarro, A. Chem. Eur. J. 2002, 8, 2574. (i) Herrera, R. P.; Guijarro, A.; Yus, M. Tetrahedron Lett. 2003, 44, 1309.

7. For a polymer-supported version of this reaction, see: (a) Gómez, C.; Ruiz, S.; Yus, M. Tetrahedron Lett. 1998, 39, 1397. (b) Gómez, C.; Ruiz, S.; Yus, M. Tetrahedron 1999, 55, 7017. (c) Yus, M.; Gómez, C.; Candela, P. Tetrahedron 2002, 58, 6207.

8. For a review, see: Guijarro, D.; Yus, M. Recent Res. Dev. Org. Chem. 1998, $2,713$. 
9. For reviews, see: (a) Nájera, C.; Yus, M. Trends Org. Chem. 1991, 2, 155. (b) Nájera, C.; Yus, M. Recent Res. Dev. Org. Chem. 1997, 1, 67. (c) Nájera, C.; Yus, M. Curr. Org. Chem. 2003, in press.

10. For a review, see: Yus, M.; Foubelo, F. Rev. Heteroatom. Chem. 1997, 17, 73.

11. See, for instance: (a) Almena, J.; Foubelo, F.; Yus, M. J. Org. Chem. 1996, 61, 1859. (b) Almena, J.; Foubelo, F.; Yus, M. Tetrahedron 1997, 53, 5563. (c) Yus, M.; Foubelo, F. Tetrahedron Lett. 2001, 42, 2469.

12. Guijarro, D.; Yus, M. Tetrahedron 1994, 50, 3447.

13. (a) Guijarro, D.; Mancheño, B.; Yus, M. Tetrahedron 1993, 49, 1327. (b) Guijarro, D.; Yus, M. Tetrahedron 1993, 49, 7761. (c) Yus, M.; Martinez, P.; Guijarro, D. Tetrahedron 2001, $57,10119$.

14. (a) Guijarro, D.; Mancheño, B.; Yus, M. Tetrahedron 1992, 48, 4593. (b) Guijarro, D.; Mancheño, B.; Yus, M. Tetrahedron 1994, 50, 8551. (c) Alonso, E.; Guijarro, D.; Yus, M. Tetrahedron 1995, 51, 11457. (d) Alonso, E.; Ramón, D. J.; Yus, M. J. Org. Chem. 1997, 62, 417. (e) Alonso, E.; Guijarro, D.; Martínez, P.; Ramón, D. J.; Yus, M. Tetrahedron 1999, 55, 11027.

15. (a) Guijarro, D.; Yus, M. Tetrahedron Lett. 1994, 35, 2965. (b) Alonso, E.; Guijarro, D.; Yus, M. Tetrahedron 1995, 51, 2699. (c) Yus, M.; Martínez, P.; Guijarro D. Synth. Commun. 2003, in press.

16. (a) Almena, J.; Foubelo, F.; Yus, M. J. Org. Chem. 1994, 59, 3210. (b) Almena, J.; Foubelo, F.; Yus, M. Tetrahedron 1994, 50, 5775. (c) Almena, J.; Foubelo, F.; Yus, M. Tetrahedron 1996, 52, 8545 .

17. The electrochemical carbon-nitrogen bond cleavage in $N$-allyl- and $N$-benzylpyridinium salts has been described: (a) Grimshaw, J.; Moore, S.; Thompson, N.; Trocha-Grimshaw, J. J. Chem. Soc., Chem. Commun. 1983, 783. (b) Grimshaw, J.; Moore, S.; Trocha-Grimshaw, J. Acta Chem. Scand., Series B 1983, B37, 485.

18. (a) Bates, R. B.; Kroposki, L. M.; Potter, D. E. J. Org. Chem. 1972, 37, 560. (b) Mills, N. S.; Shapiro, J.; Hollingsworth, M. J. Am. Chem. Soc. 1981, 103, 1263. (c) Walfort, B.; Pandey, S. K.; Stalke, P. Chem. Commun. 2001, 1640.

19. Watson, S. C.; Eastham, J. F. J. Organomet. Chem. 1967, 9, 165.

20. Sommer, H. Z.; Lipp, H. I.; Jackson, L. L. J. Org. Chem. 1971, 36, 824.

21. Lillis, V.; McKenna, J.; McKenna, J. M.; Smith, M. J.; Taylor, P. S.; Williams, I. H. J. Chem. Soc., Perkin Trans. 2 1980, 83.

22. CAS registry number 117867-96-6.

23. Chu, S. H.; Mautner, H. G. J. Org. Chem. 1966, 31, 308.

24. Sharma, M. L.; Talwar, K. K.; Gupta, A.; Kishore, L. J. Indian Chem. Soc. 1997, 74, 233; Chem. Abstr. 1997, 126, 293125. 
25. Petti, M. A.; Shepodd, T. J.; Barrans, R. E., Jr.; Dougherty, D. A. J. Am. Chem. Soc. 1988, $110,6825$. 